\title{
Erratum to: Thermochemical treatment of fly ash for synthesis of mesoporous activated carbon
}

\author{
Reyad A. Shawabkeh ${ }^{1}$ - Zaheer Aslam ${ }^{1}$ Ibnelwaleed A. Hussein ${ }^{1,2}$
}

Published online: 4 January 2016

(C) Akadémiai Kiadó, Budapest, Hungary 2015

Erratum to: J Therm Anal Calorim (2015)

122:1191-1201

DOI 10.1007/s10973-015-4964-7

The correct spelling for the last author is Hussein instead of Hussien.

The online version of the original article can be found under doi: $10.1007 / \mathrm{s} 10973-015-4964$.

Ibnelwaleed A. Hussein

ihussein@kfupm.edu.sa; ihussein@qu.edu.qa

1 Department of Chemical Engineering, King Fahd University of Petroleum and Minerals, Dhahran 31261, Saudi Arabia

2 Gas Processing Center, College of Engineering, Qatar University, P.O. Box 2713, Doha, Qatar 